\title{
Spiroplasma cantharicola sp. nov., from Cantharid Beetles (Coleoptera: Cantharidae)
}

\author{
ROBERT F. WHITCOMB,${ }^{1 *}$ C. CHASTEL, ${ }^{2}$ M. ABALAIN-COLLOC,${ }^{2}$ C. STEVENS, ${ }^{3}$ J. G. TULLY, ${ }^{4}$ \\ D. L. ROSE, ${ }^{4}$ P. CARLE, ${ }^{5}$ J. M. BOVÉ, ${ }^{5}$ R. B. HENEGAR, ${ }^{1}$ K. J. HACKETT, ${ }^{1}$ T. B. CLARK, ${ }^{1}$ \\ M. KONAI, ${ }^{1}$ AND D. L. WILLIAMSON ${ }^{6}$ \\ Insect Biocontrol Laboratory, Beltsville Agricultural Research Center, Agricultural Research Service, U.S. \\ Department of Agriculture, Beltsville, Maryland $20705^{1}$; Faculté de Médecine, 29285 Brest Cédex, ${ }^{2}$ and \\ Laboratoire de Biologie Cellulaire et Moléculaire, Institut National de la Recherche Agronomique, 33883 \\ Villenave d'Ornon Cédex, ${ }^{5}$ France; Department of Biology, Tuskegee University, Tuskegee, Alabama 36088 \\ Mycoplasma Section, Laboratory of Molecular Microbiology, National Institute of Allergy and Infectious \\ Diseases, Frederick Cancer Research Facility, Frederick, Maryland 217024; and Department of Anatomical \\ Sciences, State University of New York at Stony Brook, Stony Brook, New York $11794^{6}$
}

\begin{abstract}
Spiroplasma strain $\mathrm{CC}-1^{\mathrm{T}}$, isolated from the gut of the soldier beetle Cantharis carolinus, was serologically distinct from other spiroplasma species, groups, and subgroups. Cells of strain $\mathrm{CC}-\mathrm{1}^{\mathrm{T}}$ were shown by light microscopy to be helical, motile filaments. Electron microscopy showed that the cells were bounded by a single cytoplasmic membrane, with no evidence of a cell wall. The organism was insensitive to penicillin. Strain CC-1 ${ }^{T}$ grew well in SM-1, M1D, and SP-4 liquid media under aerobic or anaerobic conditions. The strain also grew in $1 \%$ serum fraction medium. Optimal growth occurred at $32^{\circ} \mathrm{C}$, with a doubling time of $2.6 \mathrm{~h}$, but the strain multiplied at temperatures of 10 to $37^{\circ} \mathrm{C}$. Strain $\mathrm{CC}-1^{\mathrm{T}}$ produced acid from glucose but hydrolyzed neither arginine nor urea. The guanine-plus-cytosine $(G+C)$ content of the DNA was $26 \pm 1$ mol\%. Other uncloned isolates from $C$. carolinus exhibited similar or identical serological patterns. On the basis of the data presented here, strain CC-1 ${ }^{\mathrm{T}}$ (= ATCC 43207), previously proposed as the representative strain of subgroup XVI-1, is designated the type strain of a new species, Spiroplasma cantharicola.
\end{abstract}

In 1982, adults of the soldier beetle, Cantharis carolinus (Coleoptera: Cantharidae), were found to harbor spiroplasmas in the gut but not in the hemolymph. Strain $\mathrm{CC}-1^{\mathrm{T}}$, derived from one of five isolates, was chosen as a representative of the cluster, which was designated group XVI (33) and, more recently, subgroup XVI-1 (1, 4). This group, however, eventually turned out to be complex and to contain organisms not only from beetles but from mosquitoes and flowers also. Abalain-Colloc and colleagues $(1,4)$ characterized group XVI spiroplasmas by serology, DNA-DNA homology, and polyacrylamide gel electrophoresis, and proposed recognition of three subgroups. In this classification, the cluster of spiroplasma strains and isolates from $C$. carolinus was designated subgroup XVI-1. Chastel and his colleagues, in 1985, discovered (11) a large assemblage of serologically diverse spiroplasma strains in mosquitoes in France that partially cross-reacted with strain $\mathrm{CC}-1^{\mathrm{T}}$. These spiroplasmas were later designated subgroup XVI-3 $(1,4)$. In 1983, an apparently unrelated strain (CB-1) had been isolated from the gut of a Cantharis bilineatus adult. Although minor reciprocal cross-reactivities between the two strains were observed when the strains were compared by metabolism inhibition, deformation, and growth inhibition serology, the two strains were at first regarded (unpublished data) as representatives of separate spiroplasma groups. However, studies of Shaikh et al. (28) on spiroplasma carriage by mosquitoes in Alabama revealed a strain, AEF-2, that showed substantial cross-reactivity between strains $C C-1^{\mathrm{T}}$ and $\mathrm{CB}-1$, indicating that strains $\mathrm{CC}-1^{\mathrm{T}}$ and $\mathrm{CB}-1$ belonged to a single spiroplasma group. Strain CB-1 was subsequently assigned to subgroup XVI-2 $(1,4)$. In this paper, we describe taxonomic studies on strain $\mathrm{CC}-1^{\mathrm{T}}$ (subgroup XVI-1 of

\footnotetext{
* Corresponding author.
}

Abalain-Colloc et al. $[1,4])$ that satisfy requirements for descriptions of species of the class Mollicutes (23). Strain $\mathrm{CC}-1^{\mathrm{T}}$ is designated herein as the representative of a new species of the genus Spiroplasma.

\section{MATERIALS AND METHODS}

Spiroplasma strains. Techniques for isolation of spiroplasmas from insects have been described previously (26). The $\mathrm{CC}-1^{\mathrm{T}}$ strain was isolated and cultivated by T. B. Clark on 9 June 1982 from the gut of an adult soldier beetle, $C$. carolinus. Other related strains were isolated in June 1983. Some of the genomic and serological features of strain CC-1 ${ }^{\mathrm{T}}$ have been reported earlier (33).

Strain CC-1 was purified by conventional filtration-cloning techniques (30). Representative strains of the 24 recognized groups $(19,33)$ and eight subgroups, including type strains of recognized species $(33,36)$, were cultivated for comparative studies.

Culture medium and cultivation techniques. An isolate from which strain $\mathrm{CC}-1^{\mathrm{T}}$ was derived was grown in primary culture in SM-1 liquid medium (34) at $30^{\circ} \mathrm{C}$. After five passages, the isolate was lyophilized. For characterization, the culture was recovered from ampoules, passaged twice at $30^{\circ} \mathrm{C}$, and cloned (30). Other culture media used included M1D broth (34) and serum fraction broth with $1 \%$ bovine serum fraction (32). Solid formulations of these media were prepared by adding Noble agar (Difco Laboratories, Detroit, Mich.) to achieve a final agar concentration of 0.8 to $2.25 \%$, wt/vol. Cultures on solid medium were incubated at $30^{\circ} \mathrm{C}$, either aerobically with or without $5 \%$ carbon dioxide (GasPak system [BBL Microbiology Systems, Cockeysville, Md.]) or anaerobically with $95 \% \mathrm{H}_{2}-5 \% \mathrm{CO}_{2}$ (hydrogen GasPak system [BBL]).

Temperature requirements for growth were determined by 


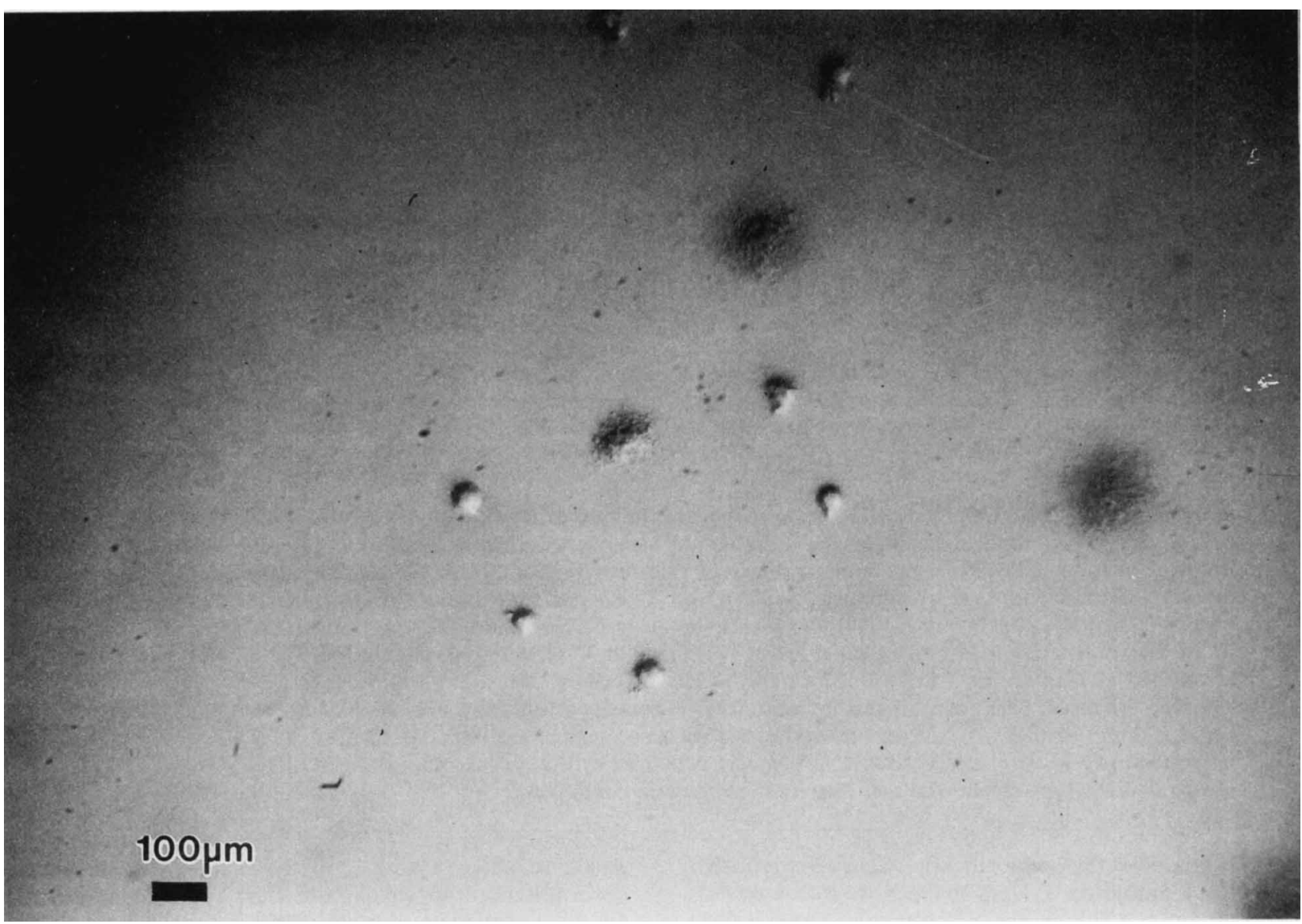

FIG. 1. Colonies of strain $\mathrm{CC}-1^{\mathrm{T}}$ on SP-4 agar medium $\left(2.25 \%\right.$ Noble agar) after 3 days of incubation at $30^{\circ} \mathrm{C}$ in an anaerobic environment.

preparing 10 -fold dilutions of strain $C C-1^{T}$ cultures in late logarithmic growth phase in M1D broth. Dilution series were incubated at $5,10,15,20,25,30,32,37$ and $41^{\circ} \mathrm{C}$. Growth of organisms was determined by observing indicator change of the media and by microscopic examination of the cultures during a 40-day observation period. The doubling times at each temperature were determined by observing the time required for medium acidification and fitting the curve to a logistic growth equation (24).

Morphological studies. Cells of strain $\mathrm{CC}^{-1}{ }^{\mathrm{T}}$ in logarithmic phase were examined by dark-field microscopy (magnification, $\times 1,250)$. For electron microscopy, strain $C C-1^{\mathbf{T}}$ was grown in approximately $20 \mathrm{ml}$ of M1D broth. Pelleted cells were fixed for $2 \mathrm{~h}$ in $3 \%$ glutaraldehyde, postfixed in $1 \%$ osmium tetroxide for $1 \mathrm{~h}$, dehydrated in acetone, embedded in Epon, sectioned, and stained with $1 \%$ aqueous uranyl acetate and Reynold's lead citrate.

Sterol requirement. Sterol requirements for growth were determined by a standard broth culture method (31).

Tests for biological and biochemical properties. Procedures for determination of carbohydrate fermentation (5), arginine and urea hydrolysis (5), hemadsorption (18), and film and spot production (17) have been described earlier. Filtration characteristics were measured in M1D broth by techniques reported previously (30).

Serological tests. Antiserum to strain $\mathrm{CC}-1^{\mathrm{T}}$ was produced in rabbits as previously described (38). Hyperimmune anti- sera to all established Spiroplasma species and groups were taken from reference collections at the Beltsville Agricultural Research Center or the National Institute of Allergy and Infectious Diseases laboratory in Frederick, Md. Metabolism inhibition and deformation tests were performed as previously described (37).

Genomic analysis. Extraction and purification of DNAs were performed as previously described (6). Estimates of the $\mathrm{G}+\mathrm{C}$ content of purified DNA of strain $\mathrm{CC}-1^{\mathrm{T}}$ were obtained by buoyant-density, melting-temperature, and high-performance liquid chromatography techniques (7). Purified DNA from Spiroplasma citri (genome size, 1,186 MDa; G+C content, $26 \pm 1 \mathrm{~mol} \%$ ) was used as a reference.

\section{RESULTS AND DISCUSSION}

Cultural and morphological properties. Strain $\mathrm{CC}-1^{\mathrm{T}}$ grew well in SM-1, M1D, SP-4, and conventional mycoplasma fluid media and aerobically or anaerobically on SP-4 solid medium. In all gaseous environments, it produced diffuse or rough colonies on SP-4 agar (Fig. 1), with some satellite growth. Fried egg colonies were never observed. The strain also grew in versions of the conventional Edward formulation of mycoplasma medium containing either horse serum (15) or bovine serum fraction (32). Growth occurred at temperatures ranging from 10 to $37^{\circ} \mathrm{C}$; optimal growth was observed at $30^{\circ} \mathrm{C}$. In broth media incubated at 5 or $41^{\circ} \mathrm{C}$, no 
TABLE 1. Growth response of strain $\mathrm{CC}-1^{\mathrm{T}}$ to cholesterol

\begin{tabular}{|c|c|c|}
\hline Supplement(s) ${ }^{a}$ & $\begin{array}{l}\text { Cholesterol } \\
\text { concn }(\mu \mathrm{g} / \mathrm{ml})\end{array}$ & $\begin{array}{c}\text { Amt of protein } \\
(\mathrm{mg} / 100 \mathrm{ml})\end{array}$ \\
\hline $1 \%$ Serum fraction (control) & 0 & $2.64^{b}$ \\
\hline None & 0 & 0.19 \\
\hline $\begin{array}{l}1 \% \text { Albumin, } 0.01 \% \text { Tween } 80 \text {, and } \\
10 \mu \mathrm{g} \text { of palmitic acid per ml }\end{array}$ & $\begin{array}{r}0 \\
1 \\
5 \\
10 \\
20\end{array}$ & $\begin{array}{l}0.38 \\
0.79 \\
1.24 \\
1.82 \\
1.96\end{array}$ \\
\hline
\end{tabular}

${ }^{a}$ Added to serum-free base medium.

${ }^{b}$ Yield from a $100-\mathrm{ml}$ volume of broth after incubation at $30^{\circ} \mathrm{C}$ for 2 days.

growth was recorded. The doubling times at 10, 15, 20, 25, 30,32 , and $37^{\circ} \mathrm{C}$ were $63.6,18.3,6.8,3.5,3.1,2.6$, and 14.4 $\mathrm{h}$, respectively. The optimum is therefore $32^{\circ} \mathrm{C}$. Dark-field microscopy of logarithmic-phase cultures of strain CC-1 ${ }^{\mathrm{T}}$ showed numerous helical, motile filaments. Electron microscopy showed filamentous cells with no evidence of a cell wall (33). Typical cells were surrounded by a single cytoplasmic membrane.

Sterol requirement. Growth of strain CC-1 ${ }^{\mathrm{T}}$ was enhanced by cholesterol supplementation of serum-free SP-4 medium (Table 1). The strain failed to grow in base broth alone, but growth was increasingly enhanced when 1 to $20 \mu \mathrm{g}$ of cholesterol per ml was included.

Biochemical and biological properties. Strain $C C-1^{T}$ produced acid from glucose, but no evidence of arginine or urea hydrolysis was observed. Strain $C C-1^{T}$ produced the film and spot reaction. Colonies of the organism on an agar medium did not hemadsorb guinea pig erythrocytes. Passage of broth cultures of strain CC-1 ${ }^{\mathrm{T}}$ through $450-\mathrm{nm}$-pore-size membrane filters reduced the viable-cell titer 10 -fold to $10^{9}$ color-changing units per ml. The titer of a broth culture filtrate obtained after consecutive passage through 300- and 220 -nm membranes was reduced about 10 -fold by each procedure, to titers of $10^{8}$ and $10^{7}$ color-changing units per $\mathrm{ml}$, respectively; the $100-\mathrm{nm}$-pore-size membrane filtrate was free of viable cells.

Serological tests. Metabolism inhibition and spiroplasma deformation tests have demonstrated $(19,33)$ that strain $\mathrm{CC}-1^{\mathrm{T}}$ is serologically unrelated to representatives of established Spiroplasma groups or species.

DNA base composition. The $\mathrm{G}+\mathrm{C}$ base composition of the DNA of strain CC-1 ${ }^{\mathrm{T}}$ was $26 \pm 1 \mathrm{~mol} \%$ (8).

Habitat. Strain $\mathrm{CC}-1^{\mathrm{T}}$ and serologically similar uncloned subgroup XVI-1 isolates (CC-2, CC-3, CC-4, and CC-6) were obtained from the guts of adult cantharid beetles. Strain CB-1 (subgroup XVI-2) was also obtained from a cantharid beetle. Studies by Chastel and colleagues in France (9-12) and Shaikh and colleagues in Alabama (28) show that mosquitoes are frequent hosts of group XVI spiroplasmas. However, the mosquito spiroplasmas were found $(1,4)$ to constitute a third subgroup (XVI-3). Members of this subgroup, because of their residence in insects that transmit arboviruses, may prove to be of special interest. In all, mosquitoes appear to carry a large number of spiroplasmas $(2,3,9-12,22,28)$, and interest in spiroplasmas as possible agents for biological control of mosquito pests has been expressed $(10,21)$. Spiroplasmas may be frank pathogens of mosquitoes (21). It is also possible that genetic manipulation could produce a specific pathogen. On the other hand, the wide occurrence of group XVI spiroplasmas in the insect world $(13,20)$, together with a possibility that they may be acquired from plant surfaces by the activities of adult insects (27), may present environmental concerns if the spiroplasmas are used for biological control. Much more needs to be learned about the biological specificity of spiroplasma serotypes of biting insects, including those occurring in tabanid flies $(14,16,25,35)$. If individual serotypes are host specific, they could be useful delivery systems of toxins produced by vectored genes. Although subgroup XVI-2 and XVI-3 spiroplasmas differ from those of strain $C C-1^{\mathrm{T}}$ by a substantial amount of DNA-DNA homology, their eventual taxonomic status remains undecided. The species name proposed herein applies only to subgroup XVI-1 organisms; members of other subgroups of group XVI can be described in terms of their group-subgroup classification.

The properties of strain $\mathrm{CC}-1^{\mathrm{T}}$ described herein fulfill proposed criteria (23) for species of the class Mollicutes. Properties mandating assignment to this class include absence of a cell wall, filterability, and penicillin resistance. The requirement of strain $\mathrm{CC}-\mathrm{i}^{\mathbf{T}}$ for sterol, its inability to utilize urea, and its helical shape and motility place this strain in the family Spiroplasmataceae (29). Finally, serological comparison of strain CC-1 ${ }^{\mathrm{T}}$ with representatives of other Spiroplasma species and groups $(19,33)$ confirms its status as a distinct species.

Description of Spiroplasma cantharicola sp. nov. Spiroplasma cantharicola (can. thar. íco.la. Gr. kantharos, scarab beetle; the L.V. colo, to inhabit; M.L. n. cantharicola, an inhabitant of a family of beetles).

Cells filamentous, helical, motile, lacking true cell walls. Colonies on solid medium with $0.8 \%$ Noble agar diffuse, without fried egg morphology.

Chemoorganotroph. Acid produced from glucose. Does not hydrolyze arginine or urea.

Film and spot reaction positive. Does not hemadsorb guinea pig erythrocytes.

Sterol requirement met by cholesterol or serum.

Temperature range 10 to $37^{\circ} \mathrm{C}$, optimum $32^{\circ} \mathrm{C}$, with a doubling time of $2.6 \mathrm{~h}$.

Serologically distinct from other established Spiroplasma species.

Isolated from gut of an adult cantharid beetle $C$. carolinus. Pathogenicity for insects not determined.

$\mathrm{G}+\mathrm{C}$ content of DNA $26 \pm 1 \mathrm{~mol} \%$, as determined by buoyant-density, melting-point, and high-performance liquid chromatography techniques.

The type strain is $\mathrm{CC}^{-1}{ }^{\mathrm{T}}$ (= ATCC 43207).

\section{ACKNOWLEDGMENTS}

This study was supported in part by Binational Agricultural Research and Development grant US-1902-90R and by U.S. Department of Agriculture Potato Research grants.

\section{REFERENCES}

1. Abalain-Colloc, M.-L. 1991. Spiroplasmes de moustiques: caractérisation de deux nouvelle espèces, et classification du groupe XVI des spiroplasmes. Thesis. Université de Bretagne Occidentale, Brest, France.

2. Abalain-Colloc, M. L., C. Chastel, J. G. Tully, J. M. Bové, R. F. Whitcomb, B. Gilot, and D. L. Williamson. 1987. Spiroplasma sabaudiense sp. nov. from mosquitoes collected in France. Int. J. Syst. Bacteriol. 37:260-265.

3. Abalain-Colloc, M. L., L. Rosen, J. G. Tully, J. M. Bové, C. Chastel, and D. L. Williamson. 1988. Spiroplasma taiwanense sp. nov. from Culex tritaeniorhynchus mosquitoes collected in Taiwan. Int. J. Syst. Bacteriol. 38:103-107. 
4. Abalain-Colloc, M. L., D. L. Williamson, P. Carle, J. H. Abalain, F. Bonnet, J. G. Tully, M. Konai, R. F. Whitcomb, J. M. Bové, and C. Chastel. 1993. Division of group XVI spiroplasmas into subgroups. Int. J. Syst. Bacteriol. 43:342-346.

5. Aluotto, B. B., R. G. Wittler, C. O. Williams, and J. E. Faber. 1970. Standardized bacteriologic techniques for characterization of Mycoplasma species. Int. J. Syst. Bacteriol. 20:35-58.

6. Carle, P., C. Saillard, and J. M. Bové. 1983. DNA extraction and purification. Methods Mycoplasmol. 1:295-299.

7. Carle, P., C. Saillard, and J. M. Bové. 1983. Determination of guanine plus cytosine content of DNA. Methods Mycoplasmol. 1:301-308.

8. Carle, P., J. G. Tully, R. F. Whitcomb, and J. M. Bové. 1989. Size of the spiroplasmal genome and guanine plus cytosine content of spiroplasmal DNA. Zentralbl. Bakteriol. Suppl. 20:889-893.

9. Chastel, C., B. Devau, F. Le Goff, A. M. Simitzis-Le Flohic, R. Gruffaz, G. Kerdraon, and B. Gilot. 1987. Mosquito spiroplasmas from France and their ecology. Isr. J. Med. Sci. 23:683686.

10. Chastel, C., B. Gilot, F. Le Goff, B. Devau, G. Kerdraon, I. Humphrey-Smith, R. Gruffaz, and A. M. Simitzis-Le Flohic. 1990. New developments in the ecology of mosquito spiroplasmas. Zentralbl. Bakteriol. Suppl. 20:455-460.

11. Chastel, C., B. Gilot, F. Le Goff, A. M. R. Gruffaz, and M.-L. Abalain-Colloc. 1985. Isolement de spiroplasmes en France (Savoie, Alpes du Nord) à partir de moustiques du genre Aedes. C.R. Acad. Sci. 300:261-266.

12. Chastel, C., and I. Humphrey-Smith. 1991. Mosquito spiroplasmas. Adv. Vector Res. 7:149-206.

13. Clark, T. B. 1982. Spiroplasmas: diversity of arthropod reservoirs and host-parasite relationships. Science 217:57-59.

14. Clark, T. B., R. V. Peterson, R. F. Whitcomb, R. B. Henegar, K. J. Hackett, and J. G. Tully. 1984. Spiroplasmas in the Tabanidae. Isr. J. Med. Sci. 20:1002-1005.

15. Edward, D. G.ff. 1947. A selective medium for pleuropneumonia-like organisms. J. Gen. Microbiol. 1:238-243.

16. French, F. E., R. F. Whitcomb, J. G. Tully, K. J. Hackett, E. A. Clark, R. B. Henegar, and D. L. Rose. 1989. Tabanid spiroplasmas of the southeast USA: new groups and correlation with host life history strategy. Zentralbl. Bakteriol. Suppl. 20:919-921.

17. Freundt, E. A. 1983. Film and spot production. Methods Mycoplasmol. 1:373-374.

18. Gardella, R. S., and R. A. Del Giudice. 1983. Hemagglutination, hemadsorption, and hemolysis. Methods Mycoplasmol. 1:379 384.

19. Guo, Y. H., T. A. Chen, R. F. Whitcomb, D. L. Rose, J. G. Tully, D. L. Williamson, X. D. Ye, and Y. X. Chen. 1990. Spiroplasma chinensis sp. nov. from flowers of Calystegia hederacea in China. Int. J. Syst. Bacteriol. 40:421-425.

20. Hackett, K. J., and T. B. Clark. 1989. The ecology of spiroplasmas, p. 113-200. In R. F. Whitcomb and J. G. Tully (ed.), The mycoplasmas, vol. 5. Academic Press, Inc., New York.

21. Humphrey-Smith, I., O. Grulet, F. Legoff, and C. Chastel. 1991. Spiroplasma (Mollicutes: Spiroplasmataceae) pathogenic for Aedes aegypti and Anopheles stephensi (Diptera: Culicidae). J. Med. Entomol. 28:219-222.
22. Hung, S. H. Y., T. A. Chen, R. F. Whitcomb, J. G. Tully, and Y. X. Chen. 1987. Spiroplasma culicicola sp. nov. from the salt marsh mosquito Aedes sollicitans. Int. J. Syst. Bacteriol. 37: $365-370$.

23. International Committee on Systematic Bacteriology Subcommittee on the Taxonomy of Mollicutes. 1979. Proposal of minimal standards for descriptions of new species of the class Mollicutes. Int. J. Syst. Bacteriol. 29:172-180.

24. Konai, M., E. A. Clark, and R. F. Whitcomb. 1992. Temperature ranges and optima of spiroplasmas. Int. Organ. Mycoplasmol. Lett. 2:137.

25. Le Goff, F., I. Humphrey-Smith, M. Leclerq, and C. Chastel. 1991. Spiroplasmas from European Tabanidae. Med. Vet. Entomol. 5:143-144.

26. Markham, P. G., T. B. Clark, and R. F. Whitcomb. 1983 Culture techniques for spiroplasmas from arthropods. Methods Mycoplasmol. 1:217-223.

27. McCoy, R. E., D. S. Williams, and D. L. Thomas. 1979. Isolation of mycoplasmas from flowers, p. 75-80. In R. E. McCoy and H. $\mathrm{Su}$ (ed.), Proceedings of the Republic of China-United States Cooperative Science Seminar, symposium series I. National Science Council, Taipei, Taiwan.

28. Shaikh, A. A., W. E. Johnson, C. Stevens, and A. Y. Tang. 1987. The isolation of spiroplasmas from mosquitoes in Macon County, Alabama. J. Am. Mosq. Control Assoc. 3:289-295.

29. Skripal, I. G. 1983. Revival of the name Spiroplasmataceae fam. nov., nom. rev., omitted from the 1980 Approved Lists of Bacterial Names. Int. J. Syst. Bacteriol. 33:408.

30. Tully, J. G. 1983. Cloning and filtration techniques for mycoplasmas. Methods Mycoplasmol. 1:173-177.

31. Tully, J. G. 1983. Tests for digitonin sensitivity and sterol requirements. Methods Mycoplasmol. 1:355-362.

32. Tully, J. G. 1984. Family II. Acholeplasmataceae Edward and Freundt 1970, p. 775-781. In N. R. Krieg and J. G. Holt (ed.) Bergey's manual of systematic bacteriology, vol. 1. Williams \& Wilkins, Baltimore.

33. Tully, J. G., D. L. Rose, E. Clark, P. Carle, J. M. Bové, R. B. Henegar, R. F. Whitcomb, D. E. Colflesh, and D. L. Williamson. 1987. Revised group classification of the genus Spiroplasma (class Mollicutes), with proposed new groups XII to XXIII. Int. J. Syst. Bacteriol. 37:357-364.

34. Whitcomb, R. F. 1983. Culture media for spiroplasmas. Methods Mycoplasmol. 1:147-158.

35. Whitcomb, R. F., K. J. Hackett, J. G. Tully, E. A. Clark, F. E. French, R. B. Henegar, D. L. Rose, and A. G. Wagner. 1989. Tabanid spiroplasmas as a model for mollicute biogeography. Zentralbl. Bakteriol. Suppl. 20:931-933.

36. Williamson, D. L., J. G. Tully, and R. F. Whitcomb. 1989. The genus Spiroplasma, p. 71-111. In R. F. Whitcomb and J. G. Tully (ed.), The mycoplasmas, vol. 5. Academic Press, Inc., New York.

37. Williamson, D. L., and R. F. Whitcomb. 1983. Special serological tests for spiroplasma identification. Methods Mycoplasmol. 2:249-259.

38. Williamson, D. L., R. F. Whitcomb, and J. G. Tully. 1978. The spiroplasma deformation test, a new serological method. Curr. Microbiol. 1:203-207. 